\title{
User Costs versus Waiting Services and Depreciation in a Model of Production
}

Erwin Diewert ${ }^{1}$

October 23, 2009

Discussion Paper 09-10

Department of Economics

University of British Columbia

Vancouver, Canada V6T 1 Z1.

Email: diewert@econ.ubc.ca

Website: http://www.econ.ubc.ca/diewert/hmpgdie.htm

\begin{abstract}
The paper develops an extension of a one period model of production involving beginning and end of the period capital stocks along with output and input flows that is due to Hicks and Edwards and Bell. This generalized Austrian model of production takes into account that end of the period capital stocks result from: (i) purchases of new investment goods; (ii) internal construction of firm capital stock components and (iii) holdings of (depreciated) capital goods that were held by the firm at the beginning of the period. These different methods of creating end of period holdings of capital stocks generally have different resource requirements and hence the one period production possibilities set is more complex than the usual one. This general model of production is used to justify the decomposition of the Jorgensonian user cost of capital into separate waiting services and depreciation components.
\end{abstract}

\section{Keywords}

Production theory, user cost of capital, waiting services, depreciation, Austrian models of production, net versus gross investment.

\section{Journal of Economic Literature Classification Codes}

D24, D92.

\footnotetext{
${ }^{1}$ The author thanks the SSHRC for financial support and acknowledges very helpful discussions with Bert Balk, Charles Hulten, Hideyuki Mizobuchi, Alice Nakamura and Paul Schreyer on the topics treated in this note. None of the above are responsible for any opinions expressed in this note.
} 


\section{Introduction}

Diewert, Mizobuchi and Nomura (2005) and Diewert and Lawrence (2006) adapted Diewert and Morrison's (1986) model of production in order to look at the determinants of the growth in the real income generated by the production sector of an economy. These determinants turned out to be: (i) productivity growth; (ii) changes in real output prices and (iii) changes in the use of capital and labour by the market production sector. These recent income generating growth accounting studies were somewhat unconventional in that they did not use the traditional user cost of capital in order to value the contribution of capital services to production ${ }^{2}$; instead these studies took depreciation out of the user cost of capital and treated it as an offset to gross investment. When depreciation is taken out of the traditional user cost of capital, the resulting price of capital services is known as the price of waiting services. ${ }^{3}$ The question we want to address in this note is whether it is legitimate (from the viewpoint of basic production theory) to take depreciation out of the user cost of capital and to then treat depreciation as separate decision variable which can then be an offset to gross investment.

It turns out that it is not straightforward to answer this legitimacy question. In section 2, we explain the starting point of our analysis: the Neo-Austrian model of production that was proposed by Hicks (1961) and Edwards and Bell (1961). However, this model is not sufficiently general to deal with depreciation in a realistic manner so the model is generalized in section 3 where we show that this Generalized Austrian model provides a justification for removing depreciation from the usual user cost formula and for treating depreciation as a separate decision variable. Section 4 concludes.

\section{The Neo-Austrian Model of Production}

In this section, we will review a generalization of the one period Austrian model of production that dates back to Böhm-Bawerk (1891). ${ }^{4}$ This Neo-Austrian model of production is based on a well established model of production that is used both by economists and thoughtful accountants as the following two quotations will show:

"We must look at the production process during a period of time, with a beginning and an end. It starts, at the commencement of the Period, with an Initial Capital Stock; to this there is applied a Flow Input of labour, and from it there emerges a Flow Output called Consumption; then there is a Closing Stock of Capital left over at the end. If Inputs are the things that are put in, the Outputs are the things that are got out, and the production of the Period is considered in isolation, then the Initial Capital Stock is an Input. A Stock Input to the Flow Input of labour; and further (what is less well recognized in the tradition, but is equally clear when we are strict with translation), the Closing Capital Stock is an Output, a Stock Output to match the Flow Output of Consumption Goods. Both input and output have stock and flow components; capital appears both as input and as output.” John R. Hicks (1961; 23).

\footnotetext{
2 The traditional user cost of capital was developed by Jorgenson and his coworkers; see Jorgenson (1963) (1989), Jorgenson and Griliches (1967) and Christensen and Jorgenson (1969).

${ }^{3}$ See Rymes (1968) (1983) on the concept of waiting services.

${ }^{4}$ Further contributions to this model were made by von Neumann (1937), Hicks (1946; 230), Malinvaud (1953) and Diewert (1977; 108-111) (1980; 472-474).
} 
"The business firm can be viewed as a receptacle into which factors of production, or inputs, flow and out of which outputs flow...The total of the inputs with which the firm can work within the time period specified includes those inherited from the previous period and those acquired during the current period. The total of the outputs of the business firm in the same period includes the amounts of outputs currently sold and the amounts of inputs which are bequeathed to the firm in its succeeding period of activity.” Edgar O. Edwards and Philip W. Bell (1961; 71-72).

Hicks and Edwards and Bell obviously had the same model of production in mind: in each accounting period, the business unit combines the capital stocks and goods in process that it has inherited from the previous period with "flow" inputs purchased in the current period (such as labour, materials, services and additional durable inputs) to produce current period "flow" outputs as well as end of the period depreciated capital stock components which are regarded as outputs from the perspective of the current period (but will be regarded as inputs from the perspective of the next period). Their model can be viewed as an Austrian model of production in honour of the Austrian economist Böhm-Bawerk (1891) who viewed production as an activity which used raw materials and labour to further process partly finished goods into finally demanded goods.

We will formalize this Neo-Austrian model of production as follows. Let Y denote a vector of outputs produced by the production unit under consideration over a period of time and let $\mathrm{P}_{\mathrm{Y}}$ denote the corresponding vector of prices. Let $\mathrm{X}$ denote a vector of flow inputs (labour services, materials, energy inputs) used by the production unit during the period and let $\mathrm{P}_{\mathrm{X}}$ be the corresponding input price vector. In addition to these flow inputs, there are $\mathrm{N}$ capital assets (including inventories) that contribute to production. These assets (transportation equipment, machinery, structures, inventories, goods in process, etc.) are broken down into equivalence classes by their age, the amount that they have been utilized and their physical characteristics. Thus $\mathrm{N}$ will generally be very large. At the beginning of the period, the production unit has available the vector $\mathrm{K}_{\mathrm{B}}$ of beginning of the period capital stocks at its disposal ${ }^{5}$ and the vector prevailing market prices for these assets is $\mathrm{P}_{\mathrm{KB}}$. At the end of the period, the production unit produces the vector $\mathrm{K}_{\mathrm{E}}$ of capital assets and the vector of anticipated end of period market prices for these assets is $\mathrm{P}_{\mathrm{KE}}$. We assume that the production unit faces the one period nominal opportunity cost of capital or interest rate $\mathrm{r}$. We assume that all revenues received during the period are simply cumulated without any reinvestment of funds and payments for flow inputs are settled up at the end of the period. The production unit's production possibilities set is a set of feasible inputs and outputs, $\left(\mathrm{Y}, \mathrm{X}, \mathrm{K}_{\mathrm{B}}, \mathrm{K}_{\mathrm{E}}\right)$, that is denoted by the set $\mathrm{S}$. Thus the production unit's one period intertemporal profit maximization problem is the following one:

(1) $\max _{Y, X, K_{B}, K_{E}}\left\{(1+r)^{-1}\left(\mathrm{P}_{\mathrm{Y}} \cdot \mathrm{Y}-\mathrm{P}_{\mathrm{X}} \cdot \mathrm{X}+\mathrm{P}_{\mathrm{KE}} \mathrm{K}_{\mathrm{E}}\right)-\mathrm{P}_{\mathrm{KB}} \mathrm{K}_{\mathrm{B}}:\left(\mathrm{Y}, \mathrm{X}, \mathrm{K}_{\mathrm{B}}, \mathrm{K}_{\mathrm{E}}\right) \in \mathrm{S}\right\}$

where $\mathrm{P}_{\mathrm{Y}} \cdot \mathrm{Y}$ denotes the inner product of the vectors $\mathrm{P}_{\mathrm{Y}}$ and $\mathrm{Y}$, etc. Note that we have treated the prices $\mathrm{P}_{\mathrm{Y}}$ and $\mathrm{P}_{\mathrm{X}}$ of the period sales and flow input purchases as end of the period prices and

\footnotetext{
${ }^{5}$ In the algebra below, we assume that the production unit purchases these beginning of the period capital stocks at the prevailing prices for these assets. In practical applications of the theory, the unit will simply be purchasing these capital stock components from itself. The important point is that there are beginning of the period opportunity costs for selling these inherited stocks that the firm faces.
} 
hence the corresponding value flows are discounted to their beginning of the period equivalents using the beginning of the period nominal interest rate r. From a practical measurement perspective, it is more useful to multiply the objective function in (1) through by $(1+r)$ and after performing this multiplication, we obtain the following equivalent profit maximization problem where prices are "antidiscounted" or "appreciated" to the end of the period rather than to the beginning of the period: ${ }^{6}$

(2) $\max _{Y, X, K_{B}, K_{E}}\left\{\mathrm{P}_{\mathrm{Y}} \cdot \mathrm{Y}-\mathrm{P}_{\mathrm{X}} \cdot \mathrm{X}+\mathrm{P}_{\mathrm{KE}} \mathrm{K}_{\mathrm{E}}-(1+\mathrm{r}) \mathrm{P}_{\mathrm{KB}} \mathrm{K}_{\mathrm{B}}:\left(\mathrm{Y}, \mathrm{X}, \mathrm{K}_{\mathrm{B}}, \mathrm{K}_{\mathrm{E}}\right) \in \mathrm{S}\right\}$.

The one period profit maximization problem defined by (2) is Diewert's (1977; 108-111) (1980; 472-474) formalization of the Hicks (1961) and Edwards and Bell (1961) accounting framework. There are two specializations of the model that could be considered for national income accounting purposes:

- An ex post version that uses the actual end of period t price as the price $\mathrm{P}_{\mathrm{KE}}$ in (2) or

- An ex ante version that uses an anticipated end of period t price as the price $\mathrm{P}_{\mathrm{KE}}$ in (2).

Diewert (1980; 476), Hill and Hill (2003) and Schreyer (2009) endorsed the ex ante version for most purposes, since it will tend to be smoother than the ex post version and it will generally lead to user costs that are closer to rental or leasing prices for the assets.

While the above neo-Austrian model of production may be satisfactory for some purposes such as for production function studies, it is not completely satisfactory for national income accounting purposes, since the role of depreciation is only implicit in the above model. Hence, in the following section, we will generalize the Neo-Austrian model of production in order to make the role of depreciation (or more accurately, deterioration) explicit.

\section{A Generalized Austrian Model of Production and Depreciation}

A problem with the above Neo-Austrian model of production is that depreciation seems to be missing from the model. More fundamentally, the problem with the model is that the end of the period capital stocks, $\mathrm{K}_{\mathrm{E}}$, can be generated in three distinct ways:

- As depreciated beginning of the period capital stocks;

- By purchasing new units of the various capital stocks from external production units and

- By building internally new units of the various capital stocks.

If a new asset is purchased externally, then this asset purchase will appear in one of the components of $\mathrm{P}_{\mathrm{X}} \cdot \mathrm{X}$, the value of flow input purchases by the production unit during the period. If a new asset is constructed by the production unit during the period, then this newly

\footnotetext{
${ }^{6}$ This is consistent with accounting treatments of assets at the beginning and end of the accounting period and cash flows that occur during the period. "Here $A_{t-1}$ is discounted as a flow dated $t-1$ and $C_{t}+A_{t}$ as a flow at $t$. This accords with the assumption conventional in discrete compounding that flows occur at the end of each period." K.V. Peasnell (1981; 56). $A_{t-1}$ and $A_{t}$ are Peasnell's counterparts to our $P_{K B} K_{B}$ and $P_{K E} K_{E}$ and $C_{t}$ is Peasnell's cash flow counterpart to our $\mathrm{P}_{\mathrm{Y}} \cdot \mathrm{Y}-\mathrm{P}_{\mathrm{X}} \cdot \mathrm{X}-\mathrm{r} \mathrm{P}_{\mathrm{KB}} \mathrm{K}_{\mathrm{B}}$. These timing conventions are discussed in more detail in Diewert (2005b; 8) and they are consistent with the use of end of period user costs as discussed in Diewert (2005a).
} 
constructed asset will show up as a component of the end of the period capital stock vector, $\mathrm{K}_{\mathrm{E}}$, and the materials and labour that went into building this new asset will also show up in various components of the input vector $\mathrm{X}$. Finally, if an asset is merely held over the period so that it was present as a component in the beginning of the period vector of capital stocks, $K_{B}$, then it will also show up as a component in the end of the period vector of capital stocks, $\mathrm{K}_{\mathrm{E}}$, unless the asset was sold or retired during the period. Thus there are three distinct ways for "producing" an end of period capital stock component and their resource requirements can be quite different. Suppose that no components of the initial capital stock vector $K_{B}$ are sold during the period. Denote the depreciated end of period vector of capital stocks that correspond to $K_{B}$ by $K_{D}$, the end of period depreciated vector of initially held capital stocks. Denote the vector of newly purchased capital equipment components by $\mathrm{I}_{1}{ }^{7}$ and the vector of newly internally produced capital equipment components by $\mathrm{I}_{2}$. In general, the resource requirements and production outcomes for producing the depreciated vector of capital stocks $K_{D}$ and the vectors of new additions to capital stocks, $\mathrm{I}_{1}$ and $\mathrm{I}_{2}$, are not equivalent. Thus the production possibilities set is not a set of $\left(\mathrm{Y}, \mathrm{X}, \mathrm{K}_{\mathrm{B}}, \mathrm{K}_{\mathrm{E}}\right)$; rather it is a set of $\left(\mathrm{Y}, \mathrm{X}, \mathrm{K}_{\mathrm{B}}, \mathrm{K}_{\mathrm{D}}, \mathrm{I}_{1}, \mathrm{I}_{2}\right)$. Since our focus here will be on describing depreciation, we will simplify the model and combine $\mathrm{I}_{1}$ and $\mathrm{I}_{2}$ into $\mathrm{I}$, a new investment aggregate of both purchased and internally produced investment goods. Thus our new production possibilities set is a set of quantity vectors of the form $\left(\mathrm{Y}, \mathrm{X}, \mathrm{K}_{\mathrm{B}}, \mathrm{K}_{\mathrm{D}}, \mathrm{I}\right)$. Let $\mathrm{S}$ denote this new feasible set of outputs and inputs for the production unit. Thus our end of period vector of capital stocks, $\mathrm{K}_{\mathrm{E}}$, is equal to the sum of the depreciated initial capital stocks held by the production unit, $\mathrm{K}_{\mathrm{D}}$, plus new gross investment (both purchased and created over the period), $\mathrm{I}$ :

(3) $K_{E} \equiv K_{D}+I$

Now substitute (3) into the objective function for (2), and we obtain the following Generalized Austrian one period profit maximization problem:

(4) $\max _{Y, X, K_{B}, K_{D}, I}\left\{\mathrm{P}_{\mathrm{Y}} \cdot \mathrm{Y}-\mathrm{P}_{\mathrm{X}} \cdot \mathrm{X}-(1+\mathrm{r}) \mathrm{P}_{\mathrm{KB}} \cdot \mathrm{K}_{\mathrm{B}}+\mathrm{P}_{\mathrm{KE}} \cdot\left(\mathrm{K}_{\mathrm{D}}+\mathrm{I}\right):\left(\mathrm{Y}, \mathrm{X}, \mathrm{K}_{\mathrm{B}}, \mathrm{K}_{\mathrm{D}}, \mathrm{I}\right) \in \mathrm{S}\right\}$.

Note that the objective function in the profit maximization problem defined by (4) can be rewritten as follows: ${ }^{8}$

\footnotetext{
${ }^{7}$ There is a complication associated with purchases of investment goods which is neglected here: if the investment good is purchased during the beginning of the period, it may give a stream of capital services during the period under consideration and at the end of the period, it will be a (partially depreciated) addition to our list of end of period capital stocks whereas if the investment good is purchased at the end of the production period, it will be a brand new addition to end of period capital stocks. This difficulty can be overcome conceptually by distinguishing a finer classification of capital goods according to their degree of depreciation during the period of purchase. Other (more sensible) solutions to this problem have been proposed by Balk (2007) and Schreyer (2009). Typically, applied economists and accountants neglect this problem and simply regard purchases of investment goods as if they yield no capital services during the period of purchase and are new additions to capital stocks at the end of the accounting period. This somewhat inaccurate treatment of new investment purchases will be approximately correct if the accounting period is fairly short.

${ }^{8}$ Note that the vector of new investment goods either internally produced by the production unit or purchased externally is valued at the prevailing end of the period prices for components of the capital stock, $\mathrm{P}_{\mathrm{KE}}$. As noted above, if the investment vector I contains units of externally purchased capital goods, then the purchase prices for these capital goods will be embedded in the $\mathrm{P}_{\mathrm{X}}$ vector and corresponding quantities purchased will be embedded in the $\mathrm{X}$ vector.
} 
(5) $P_{Y} \cdot Y-P_{X} \cdot X-(1+r) P_{K B} \cdot K_{B}+P_{K E} \cdot\left(K_{D}+I\right)=P_{Y} \cdot Y+P_{K E} \cdot I-P_{X} \cdot X-(1+r) P_{K B} \cdot K_{B}+P_{K E} \cdot K_{D}$ $=P_{Y} \cdot Y+P_{K E} \cdot I-P_{X} \cdot X-G V K$

where the gross value of capital services, GVK, for the production unit is defined as follows:

(6) $G V K \equiv(1+r) P_{K B} \cdot K_{B}-P_{K E} \cdot K_{D}$.

The above expression for the gross value of capital services does not look very familiar so it is useful to consider the following special case of the general framework. Suppose that $K_{B}$ is a scalar so that there is only one capital stock and suppose that depreciation is geometric at the constant depreciation rate $\delta$ where $0<\delta<1$. Then the end of the period depreciated capital stock, $K_{D}$, is equal to $(1-\delta)$ times the beginning of the period capital stock; i.e., we have:

(7) $\mathrm{K}_{\mathrm{D}}=(1-\delta) \mathrm{K}_{\mathrm{B}}$

Substituting (7) into (6) leads to the following expression for the gross value of capital services:

(8) $\mathrm{GVK} \equiv(1+\mathrm{r}) \mathrm{P}_{\mathrm{KB}} \mathrm{K}_{\mathrm{B}}-\mathrm{P}_{\mathrm{KE}}(1-\delta) \mathrm{K}_{\mathrm{B}}=\left[\mathrm{rP}_{\mathrm{KB}}+\delta \mathrm{P}_{\mathrm{KE}}-\left(\mathrm{P}_{\mathrm{KE}}-\mathrm{P}_{\mathrm{KB}}\right)\right] \mathrm{K}_{\mathrm{B}}$

where the expression in square brackets is a familiar discretization of Jorgenson's (1963) continuous time user cost of capital, $\mathrm{P}_{\mathrm{U}}:^{9}$

(9) $\mathrm{P}_{\mathrm{U}} \equiv \mathrm{rP}_{\mathrm{KB}}+\delta \mathrm{P}_{\mathrm{KE}}-\left(\mathrm{P}_{\mathrm{KE}}-\mathrm{P}_{\mathrm{KB}}\right)$.

Thus it can be seen that definition (6) for the value of capital services is a generalization of the familiar Jorgensonian expression for the gross value of capital services. Note that in the geometric model of depreciation, the technology restricts $K_{D}$ so that it is no longer an independent variable so that in this case, the profit maximization problem (4) collapses to the following simpler problem, which drops $\mathrm{K}_{\mathrm{D}}$ as a decision variable:

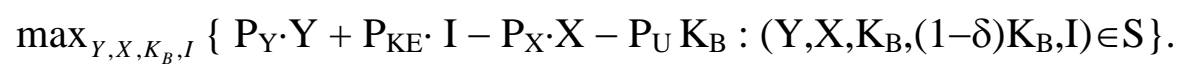

However, the geometric model of depreciation can only be a rough approximation to the "truth": increased maintenance and renovation activity will generally lead to end of the period capital stocks which are not as run down as they would be had these restoration activities not taken place and similarly, increased utilization of capital equipment will generally lead to end of the period assets which have shorter expected remaining asset lives. Thus the one period intertemporal production model defined by (4) is a more realistic depiction of reality than the traditional one period model defined by (10), which is based on rigid geometric depreciation.

\footnotetext{
${ }^{9}$ We are neglecting tax considerations here. Formula (9) was derived by Christensen and Jorgenson (1969; 302) as an approximation to a continuous time formula. The above simple discrete time derivation of (9) was used by Diewert (1974; 504), (1980; 472-473), (1992; 194) and by Hulten (1996; 155). For further discussions of user costs and the associated accounting problems, see Jorgenson (1989), Hulten (1990), Balk (2007) and Schreyer (2009).
} 
We now need to face up to a problem with the more general model (4). The problem is that the expression for the gross value of capital services does not seem to have depreciation or physical deterioration in it; i.e., price effects seem to be very much intertwined with depreciation effects in our formula (6) for the gross value of capital services in the general case. However, this difficulty can be remedied if we define the depreciation vector, $\mathrm{D}$, as the difference between the vector of beginning of the period stocks, $\mathrm{K}_{\mathrm{B}}$, and the vector of depreciated end of period stocks, $\mathrm{K}_{\mathrm{D}}:^{10}$

(11) $\mathrm{D} \equiv \mathrm{K}_{\mathrm{B}}-\mathrm{K}_{\mathrm{D}}$

The above definition of depreciation is the main new idea in this note. Now use (11) to solve for $K_{D}$ which turns out to be equal to $K_{B}-D$ and replace $K_{D}$ in (4) by this expression. Making this substitution, (4) becomes the following equivalent one period intertemporal profit maximization problem:

$$
\max _{Y, X, K_{B}, D, I}\left\{\mathrm{P}_{\mathrm{Y}} \cdot \mathrm{Y}-\mathrm{P}_{\mathrm{X}} \cdot \mathrm{X}-(1+\mathrm{r}) \mathrm{P}_{\mathrm{KB}} \cdot \mathrm{K}_{\mathrm{B}}+\mathrm{P}_{\mathrm{KE}} \cdot\left(\mathrm{K}_{\mathrm{B}}-\mathrm{D}+\mathrm{I}\right):\left(\mathrm{Y}, \mathrm{X}, \mathrm{K}_{\mathrm{B}}, \mathrm{K}_{\mathrm{B}}-\mathrm{D}, \mathrm{I}\right) \in \mathrm{S}\right\}
$$

The objective function in the profit maximization problem defined by (12) can be rewritten as follows: ${ }^{11}$

$$
\begin{aligned}
P_{Y} \cdot Y & -P_{X} \cdot X-(1+r) P_{K B} \cdot K_{B}+P_{K E} \cdot\left(K_{B}-D+I\right) \\
& =P_{Y} \cdot Y+P_{K E} \cdot I-P_{X} \cdot X-(1+r) P_{K B} \cdot K_{B}+P_{K E} \cdot\left(K_{B}-D\right) \\
& =P_{Y} \cdot Y+P_{K E} \cdot I-P_{X} \cdot X-\left[r P_{K B}-\left(P_{K E}-P_{K B}\right)\right] \cdot K_{B}-P_{K E} \cdot D \\
& =P_{Y} \cdot Y+P_{K E} \cdot I-P_{X} \cdot X-N V K-V D
\end{aligned}
$$

where the net value of capital services, NVK, and the value of physical depreciation or deterioration over the period (at end of period prices), VD, for the production unit are defined as follows:

(14) $\mathrm{NVK} \equiv\left[\mathrm{rP}_{\mathrm{KB}}-\left(\mathrm{P}_{\mathrm{KE}}-\mathrm{P}_{\mathrm{KB}}\right)\right] \cdot \mathrm{K}_{\mathrm{B}}{ }^{12}$;

(15) $\mathrm{VD} \equiv \mathrm{P}_{\mathrm{KE}} \cdot \mathrm{D}$.

Definition (15) seems to be a satisfactory definition of the value of depreciation in the Generalized Austrian model of production (even though it will be very difficult to implement this

\footnotetext{
${ }^{10}$ Note that the definition of $\mathrm{D}$ applies only to assets which were held by the production unit through the entire period so that we are assuming that no beginning of the period assets held by the firm were sold during the period. The case where beginning of the period assets are sold during the period under consideration can be dealt with at the cost of additional algebraic complexity; Diewert and Smith (1994) deal with these complexities for the case of inventory stocks.

${ }^{11}$ Note that the vector of new investment goods I which is either internally produced by the production unit or purchased externally is valued at the prevailing end of the period prices for components of the capital stock, $\mathrm{P}_{\mathrm{KE}}$.

${ }^{12}$ If there are $\mathrm{N}$ types of capital, the end of period anticipated price of the nth type of capital, $\mathrm{P}_{\mathrm{KEn}}$, can be set equal to $\left(1+i_{n}\right) P_{K B n}$, where $P_{K B n}$ is the beginning of the period price of the nth type of capital and $i_{n}$ is the anticipated asset inflation rate for asset $n$. Using this notation, (14) becomes $N V K=\sum_{N=1}{ }^{N}\left[r-i_{n}\right] P_{K B n} K_{B n}$ where $r-i_{n}$ can be interpreted as an asset specific real interest rate for asset $n$.
} 
definition in practice). Note that the net value of capital services, NVK, is equal to the gross value of capital services, GVK, less the value of depreciation, VD.

At this stage, it is convenient to shift from the production possibilities set $\mathrm{S}$ that was defined at the beginning of this section, which it will be recalled, involved feasible combinations of outputs $\mathrm{Y}$, inputs $\mathrm{X}$, beginning of the period capital stocks $\mathrm{K}_{\mathrm{B}}$, the depreciated end of period counterparts $\mathrm{K}_{\mathrm{D}}$ to the beginning of the period capital stocks and I, the vector of externally purchased and internally constructed new assets. We will now use $S$ and definition (11) in order to define a new production possibilities set $\mathrm{S}^{*}$ that involves combinations of $\mathrm{Y}, \mathrm{X}, \mathrm{K}_{\mathrm{B}}, \mathrm{I}$ and $\mathrm{D}$ so that $\mathrm{D}$ replaces $\mathrm{K}_{\mathrm{E}}$ as a decision variable:

(16) $\left(Y, X, K_{B}, D, I\right) \in S^{*}$ if and only if $\left(Y, X, K_{B}, K_{B}-D, I\right) \in S$.

Using (13) and (16), our general Generalized Austrian production profit maximization problem can be written as follows:

$$
\begin{aligned}
& \text { (17) } \max _{Y, X, K_{B}, D, I}\left\{\mathrm{P}_{\mathrm{Y}} \cdot \mathrm{Y}+\mathrm{P}_{\mathrm{KE}} \cdot \mathrm{I}-\mathrm{P}_{\mathrm{X}} \cdot \mathrm{X}-\left[\mathrm{rP}_{\mathrm{KB}}-\left(\mathrm{P}_{\mathrm{KE}}-\mathrm{P}_{\mathrm{KB}}\right)\right] \cdot \mathrm{K}_{\mathrm{B}}-\mathrm{P}_{\mathrm{KE}} \cdot \mathrm{D}:\left(\mathrm{Y}, \mathrm{X}, \mathrm{K}_{\mathrm{B}}, \mathrm{D}, \mathrm{I}\right) \in \mathrm{S}^{*}\right\}
\end{aligned}
$$

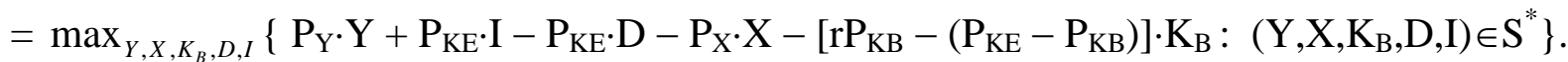

In the first line of (17), we interpret the value of depreciation, $\mathrm{P}_{\mathrm{KE}} \cdot \mathrm{D}$, as part of primary inputs whereas in the second line of (17), we interpret it as an offset to the value of gross investment, $\mathrm{P}_{\mathrm{KE}}$.I. Either interpretation appears to be consistent with the Generalized Austrian production theoretic framework.

To show that our "new" accounting scheme is not very different from existing accounting practices, we define the net investment vector $\mathrm{I}_{\mathrm{N}}$ as the difference between the vector of end of period and beginning of period capital stocks, $K_{E}$ and $K_{B}$ respectively, and show that net investment is equal to the familiar gross investment vector I less the depreciation vector $\mathrm{D}$ :

$$
\text { (18) } \begin{aligned}
\mathrm{I}_{\mathrm{N}} & \equiv \mathrm{K}_{\mathrm{E}}-\mathrm{K}_{\mathrm{B}} \\
& =\left(\mathrm{K}_{\mathrm{D}}+\mathrm{I}\right)-\left(\mathrm{D}+\mathrm{K}_{\mathrm{D}}\right) \\
& =\mathrm{I}-\mathrm{D} .
\end{aligned}
$$

Roughly speaking, Diewert and Morrison (1986) used the first line of (17) in their two stage maximization procedure. In the first stage, they maximized the value added generated by the private production sector of an economy subject to the constraints of technology; i.e., their first stage maximization problem was the following one, which defines the economy's market sector gross domestic product function, $\pi$ :

(19) $\pi\left(P_{Y}, P_{K E} ; X, K_{B}, D\right) \equiv \max _{Y, I}\left\{P_{Y} \cdot Y+P_{K E} \cdot I:\left(Y, X, K_{B}, D, I\right) \in S^{*}\right\}$.

The second stage maximization DM maximization problem is the following one which involves the gross value of capital services:

(20) $\max _{X, K_{B}, D}\left\{\pi\left(\mathrm{P}_{\mathrm{Y}}, \mathrm{P}_{\mathrm{KE}} ; \mathrm{X}, \mathrm{K}_{\mathrm{B}}, \mathrm{D}\right)-\mathrm{P}_{\mathrm{X}} \cdot \mathrm{X}-\left[\mathrm{rP}_{\mathrm{KB}}-\left(\mathrm{P}_{\mathrm{KE}}-\mathrm{P}_{\mathrm{KB}}\right)\right] \cdot \mathrm{K}_{\mathrm{B}}-\mathrm{P}_{\mathrm{KE}} \cdot \mathrm{D}\right\}$. 
On the other hand, Diewert, Mizobuchi and Nomura (2005) and Diewert and Lawrence (2006) maximized the net value added generated by the private production sector of an economy subject to the constraints of technology; i.e., their first stage maximization problem was the following one, which defines the economy's market sector net domestic product function, $\pi^{*}$ :

(21) $\pi^{*}\left(\mathrm{P}_{\mathrm{Y}}, \mathrm{P}_{\mathrm{KE}}, \mathrm{P}_{\mathrm{KE}} ; \mathrm{X}, \mathrm{K}_{\mathrm{B}}\right) \equiv \max _{\mathrm{Y}, \mathrm{I}, \mathrm{D}}\left\{\mathrm{P}_{\mathrm{Y}} \cdot \mathrm{Y}+\mathrm{P}_{\mathrm{KE}} \cdot \mathrm{I}-\mathrm{P}_{\mathrm{KE}} \cdot \mathrm{D}:\left(\mathrm{Y}, \mathrm{X}, \mathrm{K}_{\mathrm{B}}, \mathrm{D}, \mathrm{I}\right) \in \mathrm{S}^{*}\right\}$.

The second stage maximization DMN maximization problem is the following one which involves the net value of capital services:

(22) $\max _{X, K_{B}}\left\{\pi^{*}\left(\mathrm{P}_{\mathrm{Y}}, \mathrm{P}_{\mathrm{KE}}, \mathrm{P}_{\mathrm{KE}} ; \mathrm{X}, \mathrm{K}_{\mathrm{B}}\right)-\mathrm{P}_{\mathrm{X}} \cdot \mathrm{X}-\left[\mathrm{rP}_{\mathrm{KB}}-\left(\mathrm{P}_{\mathrm{KE}}-\mathrm{P}_{\mathrm{KB}}\right)\right] \cdot \mathrm{K}_{\mathrm{B}}\right\}$

Thus it appears that both the gross capital services model of production and the net capital services model have an equally valid justification from the viewpoint of the Generalized Austrian model of production. The choice of which model to use depends on the particular problem at hand.

\section{Conclusion}

The question that this note attempts to answer is: can depreciation be taken out of the usual user cost of capital and be treated as a separate decision variable? Using a generalization of the Hicks (1961) and Bell and Edwards (1961) Neo-Austrian model of production, the answer appears to be yes. Thus there does not appear to be any logical difficulty in treating depreciation as a offset to gross investment in a model of production as has been done recently by Diewert, Mizobuchi and Nomura (2005), Diewert and Lawrence (2006), Lawrence, Diewert and Fox (2006) and Balk (2007) (2009).

\section{References}

Balk, B.M. (2007), "Measuring productivity change without neoclassical assumptions: a conceptual analysis”, Discussion Paper 09023, Statistics Netherlands, The Hague.

Böhm-Bawerk, E. V. (1891), The Positive Theory of Capital, W. Smart (translator of the original German book published in 1888), New York: G.E. Stechert.

Christensen, L.R. and D.W. Jorgenson (1969), “The Measurement of U.S. Real Capital Input, 1929-1967”, Review of Income and Wealth 15, 293-320.

Balk, B.M. (2009), “On the Relation between Gross Output and Value Added Based Productivity Measures: The Importance of the Domar Factor”, 13, Macroeconomic Dynamics, Supplement S2, 241-267.

Diewert, W.E. (1974), “Intertemporal Consumer Theory and the Demand for Durables”, Econometrica 42, 497-516. 
Diewert, W.E. (1977), “Walras' Theory of Capital Formation and the Existence of a Temporary Equilibrium’, pp. 73-126 in Equilibrium and Disequilibrium in Economic Theory, G. Schwödiauer (ed.), Dordrecht: D. Reidel.

Diewert, W.E. (1980), “Aggregation Problems in the Measurement of Capital”, pp.433-528 in The Measurement of Capital, edited by D. Usher, Studies in Income and Wealth, Vol. 45, National Bureau of Economics Research, University of Chicago Press, Chicago.

Diewert, W.E. (1992), “The Measurement of Productivity”, Bulletin of Economic Research 44, 165-198.

Diewert, W.E. (2005a), 'Issues in the Measurement of Capital Services, Depreciation, Asset Price Changes and Interest Rates', pp. 479-542 in Measuring Capital in the New Economy, C. Corrado, J. Haltiwanger and D. Sichel (eds.), Chicago: University of Chicago Press.

Diewert, W.E. (2005b), “The Measurement of Capital: Traditional User Cost Approaches”, Chapter 1 of The Measurement of Business Capital, Income and Performance, Tutorial presented at the University Autonoma of Barcelona, Spain, September 21-22, 2005, revised December, 2005. http://www.econ.ubc.ca/diewert/barc1.pdf

Diewert, W.E. and D. Lawrence (2006), Measuring the Contributions of Productivity and Terms of Trade to Australia's Economic Welfare, Consultancy Report to the Productivity Commission, Australian Government, Canberra, March.

Diewert, W.E., H. Mizobuchi and K. Nomura (2005), “On Measuring Japan’s Productivity, 1955-2003”, Discussion Paper 05-22, Department of Economics, University of British Columbia, Vancouver, B.C., Canada, V6T 1 Z1.

Diewert, W.E. and C.J. Morrison (1986), “Adjusting Output and Productivity Indexes for Changes in the Terms of Trade”, Economic Journal 96, 659-679.

Diewert, W.E. and A.M. Smith (1994), “Productivity Measurement for a Distribution Firm”, The Journal of Productivity Analysis 5, 335-347.

Edwards, E.O. and P.W. Bell (1961), The Theory and Measurement of Business Income, Berkeley: University of California Press.

Hicks, J.R. (1946), Value and Capital, Second Edition, Oxford: Clarendon Press.

Hicks, J.R. (1961), "The Measurement of Capital in Relation to the Measurement of Other Economic Aggregates”, pp. 18-31 in The Theory of Capital, F.A. Lutz and D.C. Hague (eds.), London: Macmillan.

Hill, R.J. and T.P. Hill (2003), “Expectations, Capital Gains and Income”, Economic Inquiry 41, 607-619.

Hulten, C.R. (1990), “The Measurement of Capital”, pp. 119-152 in Fifty Years of Economic Measurement, E.R. Berndt and J.E. Triplett (eds.), Studies in Income and Wealth, 
Volume 54, The National Bureau of Economic Research, Chicago: The University of Chicago Press.

Hulten, C.R. (1996), “Capital and Wealth in the Revised SNA”, pp. 149-181 in The New System of National Accounts, J.W. Kendrick (ed.), New York: Kluwer Academic Publishers.

Jorgenson, D.W. (1963), “Capital Theory and Investment Behaviour”, American Economic Review 53:2, 247-259.

Jorgenson, D.W. (1989), “Capital as a Factor of Production”, pp. 1-35 in Technology and Capital Formation, D.W. Jorgenson and R. Landau (eds.), Cambridge MA: The MIT Press.

Jorgenson, D.W. and Z. Griliches (1967), “The Explanation of Productivity Change”, The Review of Economic Studies 34, 249-283.

Lawrence, D.A., W.E. Diewert and K.J. Fox (2006), "Who Benefits from Economic Reform: The Contribution of Productivity, Price Changes and Firm Size to Profitability”, Journal of Productivity Analysis 26, 1-13.

Malinvaud, E. (1953), “Capital Accumulation and the Efficient Allocation of Resources”, Econometrica 21, 233-268.

Peasnell, K.V. (1981), “On Capital Budgeting and Income Measurement”, Abacus 17(1), 52-67.

Rymes, T.K. (1968), "Professor Read and the Measurement of Total Factor Productivity”, The Canadian Journal of Economics 1, 359-367.

Rymes, T.K. (1983), "More on the Measurement of Total Factor Productivity”, The Review of Income and Wealth 29 (September), 297-316.

Schreyer, P. (2009a), Measuring Capital, Statistics Directorate, National Accounts, STD/NAD(2009)1, Paris: OECD.

von Neumann, J. (1937), “Über ein Ökonomisches Gleichungssystem und eine Verallgemeinerung des Brouwerschen Fixpunktsatzes”, Ergebnisse eines Mathematische Kolloquiums 8, 73-83; translated as “A Model of General Economic Equilibrium”, Review of Economic Studies (1945-6) 12, 1-9. 